\title{
AN ETERNAL PLANTING, A HOUSE OF HOLINESS: \\ THE SELF-UnDERSTANDING \\ Of THE DeAd Sea Scrolls COMMUNity ${ }^{1}$
}

\author{
Paul N.W. Swarup
}

This dissertation is a study of two metaphors, 'an eternal planting' and 'a house of holiness', which were used extensively by the DSS community in expression of their self-understanding. The sectarian writings and non-sectarian writings used by the community have been examined in order to bring out the theology behind these two metaphors. Fourteen ${ }^{2}$ different text excerpts have been examined, each treated initially as an individual, discrete passage and then placed within the framework of the document in which it is found, and finally within the Qumran corpus as a whole. Each passage is compared and contrasted primarily with the Hebrew Bible to see how the text has been reworked or nuanced to suit its new context. Once this is done, the theology underlying the two metaphors is discussed. It is concluded that these two metaphors express the deep yearning of the DSS community for a complete restoration of Israel, for a return to Edenic conditions as before the Fall, and for a temple which was pure. These metaphors contribute to the community's self-understanding of themselves as the 'eternal planting', or True Israel, the faithful remnant, who practised justice and righteousness and awaited the eschaton. They understood themselves to be a proleptic temple in advance of the eschatological temple to be built by God. They were also the true priests, functioning in God's heavenly temple carrying

1 Ph.D. thesis, University of Cambridge, 2002; supervisor: Prof. R.P. Gordon.

2 (1) $1 \mathrm{QH}^{\mathrm{a}}$ XIV (VI):13b-19a; 4Q428 Frg. 8:1-5; 4Q429 Frg. 4 I:1-5; (2) $1 \mathrm{QH}^{\mathrm{a}}$ XVI (VIII):4-13, 20b-26; 1QH ${ }^{\mathrm{b}}$ Frg. 2; 4QH ${ }^{\mathrm{b}}$ Frg. 10:11-12; (3) 1QS VIII:1-10; (4) 1QS XI:7b-9a; (5) CD I:5b-8a; 4QD (4Q266) Frg. 2 I:10-12; 4QD ${ }^{\mathrm{c}}$ (4Q268) Frg. 1:12b-15a; (6) 4Q418 Frgs. 81, 81a: 7b-14; (7) 4Q423 Frgs. 1, 2:1-9; (8) 4QFlor. (4Q174) III:1-13; (9) 4QShirShabb ${ }^{\mathrm{a}}$ (4Q400) Frg. $1 \mathrm{I}: 1-21$; (10) TS (11Q19) XXIX: 2-10; (11) 1QS V:4-7; (12) 1QS IX:3-6; (13) 1QpHab XII: 1-10; and (14) 4QpIsa ${ }^{\mathrm{d}}$ Frg. 1:1-8. 
out the priestly ministry of atonement, teaching, intercession, and blessing. These two metaphors appear to be quite distinct at first sight, but on closer examination they are seen to convey many complementary theological ideas. The reasons why the two metaphors of planting and sanctuary were important for the DSS community can be seen in the variety of theological themes that they embrace. The following are the key theological themes that arise out of the use of these two metaphors.

\section{The Eternal Plant as the True Israel: The Righteous Remnant}

The metaphor of the 'plant/planting' covers a wide spectrum of meanings within the biblical tradition. I have shown that the selfunderstanding of the DSS community as the 'Eternal Plant' enabled them to see themselves as the True Israel and the righteous remnant. The idea of the remnant was complicated during the exile because of the tension that existed between the historical reality of Israel in exile and the theological belief that they were God's elect. It is in this context that we see the idea of the return of the remnant become a central theme in Jewish eschatological hope. Even after Israel had returned from exile physically, the promises of restoration seemed to have been only partially fulfilled. And although the remnant had returned, many had forgotten what the Lord had done and were pursuing their own interests (cf. Ne. 9:35). This was particularly so with the high-priest and the temple personnel who were more interested in power and politics than turning the hearts of the people towards the Lord (Cf. 1QpHab VIII:8-IX:12). Since the highpriesthood was corrupt and the temple defiled there needed to be an alternative for those who pursued righteousness. The origins of the DSS community are rooted in this milieu where there was a perceived need for a faithful remnant. It is in this context that the metaphor of the 'plant/planting' is applied to the DSS community. The community was raised as the 'root of the planting', the remnant, who would bring in the fulfilment of the promises made by the prophets concerning the eschaton.

As much as the metaphor of the 'plant/planting' enabled the DSS community to understand themselves to be the True Israel, it also helped them to identify themselves as standing in a line of strong continuity with the Abrahamic covenant. Just as Abraham was called to be a blessing to the nations, they saw themselves as called to be a blessing to others. The DSS community now took up doing justice and righteousness, which were part of the conditions laid down for 
Abraham. They were to practise justice and righteousness as a community in order to lead a life which was perfect and blameless. Similar imagery occurs in Jubilees concerning the 'plant of righteousness'. According to the promise found in Jubilees, God would raise a 'righteous plant' from the descendants of Abraham and Isaac. The DSS community saw themselves standing in the line of Abraham's descendants and so identified their community as the inheritors of the promises made to him.

Another theme that the metaphor of the 'plant/planting' embraces is that of the 'World Tree'. In the first psalm discussed, in Hodayot $\left(1 \mathrm{QH}^{\mathrm{a}} \mathrm{XIII}[\mathrm{V}]: 20-\mathrm{XV}[\mathrm{VII}]: 5\right)$, the eternal plant portrays the faithful remnant as those who would grow, be fruitful, and extend their influence to all creation. Though the 'World Tree' is usually symbolic of kings and kingdoms in a negative sense within the biblical tradition, in the self-understanding of the DSS community the 'World Tree' image has a positive role. Its beginnings may have been small, but its influence extended far and wide and would last forever. It did not exist as a tree to be felled, but rather as a tree which was to be a blessing to all who came under its shade. There is a universalistic dimension here. Election was not for the sake of being exclusive, but for the sake of benefiting others.

The metaphor of the 'Eternal Planting' in 4QInstruction carries with it the idea of the community being God's holy people and fulfilling the role of priests. The DSS community took up this piece of wisdom literature, as it was very much in line with their selfunderstanding and ideology. They were asked to sanctify themselves, just as God had consecrated Aaron and his sons for the priesthood. They were the 'holy ones' who were called by his name and who had been fashioned according to the image and character of God. They saw themselves as a separated people chosen by God to be holy and to serve as his priests. The ministry of the priesthood in turning away the wrath of God in the example of Phinehas acted as a paradigm for their own ministry. They fulfilled the role of the priests by interceding for the people, making atonement, judging the wicked, and blessing the people in the name of the Lord. The teaching of the Torah, which was also one of the duties of the priests, was fulfilled by the members of the DSS community, as was the maintaining of the purity of the sanctuary. Since the Jerusalem temple was defiled, they understood their own community as a proleptic sanctuary, and therefore maintaining purity within the community was one of their chief concerns. The theme of priesthood is also found in the Songs of the 
Sabbath Sacrifice. Here there is liturgical communion with the angelic/human priesthood in the heavenly temple. The members of the DSS community appropriated this liturgy as they saw themselves concelebrating with the angelic community in this heavenly temple. This was particularly important for the priestly community because they could not have had a better means of confirming their true and pure priesthood than to show themselves ministering in the heavenly temple.

\section{Eden and the Sanctuary}

The metaphors of the plant/planting and the temple/sanctuary bring together the ideas of Eden and the Sanctuary. The metaphor of the eternal plant has Edenic echoes, and therefore was of importance for the self-understanding of the community inasmuch as they saw themselves as a restored eschatological community. I have shown that, in $1 \mathrm{QH}^{\mathrm{a}}$, Eden is linked with the idea of paradise where the psalmist and the remnant would be in the presence of God. The eternal plant is portrayed as having roots going down to Sheol that are watered by the streams of Eden. The picture of the righteous as plants in a garden has strong biblical roots. Isaianic traditions of God comforting Zion and transforming her into a well-watered planting, and the biblical tradition of the righteous compared to a palm tree and to the cedars of Lebanon, are now applied to the community. Furthermore, God's promise of a restored Israel and a restored land that will be like the garden of Eden is now used metaphorically by the community. They are the garden, the eternal plant whom God has restored. They are also the eternal spring whose waters never end. Eden is a place set aside for the faithful and the righteous. The motif of Eden included the unmediated presence of the deity, which the community saw as part of their inheritance.

The concept of Eden, referred to as paradise, being a place of rest for the righteous was common during this period. Fishbane notes that, among the archetypal expressions of sacred geography in the Hebrew Bible, the imagery of Eden is dominant. Eden is located in the primordial past and is set on a mountain from which four streams flow to the quadrants of the earth. It is seen as the source of sustenance and blessing for all creation, and contains jewels and riches together with the repositories of the secret powers of life and knowledge in the respective trees of life and of knowledge. The garden of Eden therefore symbolizes the primordial harmony which existed before the transgression of Adam. It was as a consequence of Adam's 
disobedience that humankind forfeited existence in Eden and were cast out and condemned to the dislocations of historical existence. Fishbane further suggests that Eden is a literary residue of an archetypal memory of spatial harmony and divine bounty. This is the basis for an inner-biblical nostalgia for a return to this original condition. Eliade states that most ancient societies betray a nostalgia for Paradise, the desire to recover the state of freedom and goodness that existed before the expulsion from Eden. The desire is for a healing of relationships between human beings and other living creatures, and for a healing of the relationship with God in which the restored Adam meets with God and speaks directly with him face to face as he did in illo tempore. It is not only a nostalgia on the part of ancient societies, but also of Israel, particularly with the dislocation of the exile and the destruction of the land and the temple. It is in this context that the symbolism of Eden becomes more poignant.

The post-exilic prophets use the Edenic imagery as a symbol of restoration of both the people and the land (Is. 51:3; Ezk. 36:35). The longing for restoration and return to the land from which the people were evicted is all seen as part of this Edenic hope. In the Ezekielan oracle about the dry bones coming to life the re-creation of the corporate body of Israel is seen like a new Adam emerging with new flesh and a new spirit (Ezk. 37:4-9). The blending of Adamic and Edenic imagery enables national nostalgia and primordial fantasies to come together. For the DSS community the fusing of these two images contributed to their expression of their own hopes and aspirations of being in Eden - hopes that were proleptically realised with the coming of their community into existence.

The reworking of the Edenic traditions in post-exilic prophecy occurs explicitly in connection with the new Temple. Ezekiel presents the picture of the future Temple in Zion from which streams flow, providing healing and sustenance for the nations. The Temple again is seen as the place where God will dwell in the midst of human beings just as he did before. Ezekiel brings together Temple and Edenic imagery and expresses the same nostalgia for spatial harmony and blessing and their realization in the future. This reveals the depth of the Israelite yearning for restoration and for the presence of God in their midst in the Temple. Similarly, the prophet Joel compares the promised land to the garden of Eden (כגן־עדן; Joel 2:3) and sees its restoration in terms of a fountain which flows from the temple of the Lord and sustains the people (4:18-21). Zechariah also speaks of a 
day when living waters will flow out from Jerusalem and sustain the earth (Zc. 14:8-11).

The מקדש ארם, or the 'sanctuary of men/Adam', is a motif that the community also adapt in description of themselves. Though other scholars have suggested that this term is a reference to a physical building, the meaning that emerges in the context of the commentary is that of the DSS community as a proleptic sanctuary. They anticipate a temple cult before the final end, and they see themselves being restored to the likeness of Adam as God intended him to be. The 'sanctuary of Adam' also indicates that the community-sanctuary is part of God's ultimate purpose, that is, the restoration of Eden.

Although the DSS community lived in the wilderness at Qumran, away from the polluted and defiled temple, its members firmly believed that God's presence was with them. More than that, they expected a new temple in the immediate future, in which God would dwell forever. Until that time they saw themselves as a proleptic sanctuary awaiting the eschatological sanctuary which God himself would build. The descriptions of the temple building and the detail involved in the description of sacrifice in $11 \mathrm{QT}^{\mathrm{a}}$ anticipated the return of proper worship on a grand scale in which the members of their priestly community would fully participate.

The metaphors of the 'plant/planting' and the 'temple/sanctuary' used by the DSS community were therefore vital for their understanding of themselves as a group set apart from the rest of Israel. It was these two metaphors that gave them a pragmatic ideology, which they translated into practice as a community. The two metaphors are like two sides of the same coin. They may look different, but on closer inspection they represent theological ideas that complement each other. The community appropriated these two traditions and adapted them to suit their new context, and this gave the community the dynamism and the vitality to fulfil their selfappointed role as - an eternal planting, a house of holiness. 